\title{
Interactions between controlled atmospheres and low temperature tolerance: a review of biochemical mechanisms
}

\author{
Leigh Boardman ${ }^{1}$, Jesper Givskov Sørensen ${ }^{2}$, Shelley A. Johnson ${ }^{1}$ and John S. Terblanche ${ }^{1 *}$ \\ Department of Conservation Ecology and Entomology, Stellenbosch University, Stellenbosch, South Africa \\ 2 Department of Bioscience, Aarhus University, Silkeborg, Denmark
}

Edited by:

Sylvia Anton, Institut National de la

Recherche Agronomique, France

\section{Reviewed by:}

Nigel Andrew, University of New

England, Australia

Klaus Fischer, Greifswald University,

Germany

\section{*Correspondence:}

John S. Terblanche, Department of Conservation Ecology and

Entomology, Stellenbosch University

Private Bag X1, Matieland 7602,

South Africa.

e-mail: jst@sun.ac.za
Controlled atmosphere treatments using carbon dioxide, oxygen, and/or nitrogen, together with controlled temperature and humidity, form an important method for post-harvest sterilization against insect-infested fruit. However, in insects, the cross tolerance and biochemical interactions between the various stresses of modified gas conditions and low temperature may either elicit or block standard stress responses which can potentiate (or limit) lethal low temperature exposure. Thus, the success of such treatments is sometimes erratic and does not always result in the desired pest mortality. This review focuses on the biochemical modes of action whereby controlled atmospheres affect insects low temperature tolerance, making them more (or occasionally, less) susceptible to cold sterilization. Insights into the integrated biochemical modes of action may be used together with the pests' low temperature tolerance physiology to determine which treatments may be of value in post-harvest sterilization.

Keywords: thermal biology, stored product, pest management, biological control

\section{INTRODUCTION}

Many treatment regimes rely on one of several stresses [e.g., temperature/controlled atmospheres (CAs)] to reduce survival of insects for pest management or post-harvest disinfestation. However, current research is increasingly exploring the use of multiple, combined, or sequential stresses to act synergistically and enhance insect mortality rates, while reducing commodity damage. The phasing out of numerous chemicals previously used to sterilize fruit and other commodities has prompted renewed interest in CA treatments [reviewed by Fields and White (2002)]. Controlled atmosphere treatments usually involve augmenting temperature sterilization with either high $\mathrm{CO}_{2}(18-90 \mathrm{kPa})$ or low $\mathrm{O}_{2}(0-$ $11.5 \mathrm{kPa}$; Hallman and Denlinger, 1998). These gas conditions are frequently used along with controlled humidity, and can be combined to give a high $\mathrm{CO}_{2}$ and low $\mathrm{O}_{2}$ environment. There has also been research into using ozone for pest control in stored produce (Tiwari et al., 2010). Cross tolerance of insects to different environmental stressors can disrupt post-harvest control measures in unexpected ways and the success of CA treatments is speciesdependent, erratic and does not always result in additional pest mortality (e.g., Navarro, 1978; see Mitcham et al., 2001; Pryke and Pringle, 2008).

In general, CAs at high temperatures reduce the exposure time of fruit thereby reducing fruit damage. However, some commodities are particularly intolerant to warm temperatures (e.g., grapes and cut flowers). At low temperatures, CAs can improve pest mortality during low temperature sterilization, and sometimes shorten the treatment duration too. Whilst the effects of high temperature treatments together with CAs are relatively well documented for several insect pests (e.g., Neven and Rehfield-Ray, 2006), CA treatments coupled with low temperature exposures are not well understood. Treatments with minimal deleterious effects on fresh commodities are challenging to develop (but see Table 1 for a list of published potentially viable low temperature CA protocols). The inconsistent results may indicate that the pre-treatments either elicit or block standard stress responses which potentiate (or limit) lethal low temperature exposure. In addition, insects may also be exposed to conditions that enhance thermal tolerance during the harvesting process prior to sterilization or during the actual CA process which could ultimately affect treatment efficacy.

This mini-review focuses on the biochemical mechanisms whereby CAs affect insect low temperature tolerance, potentially making them more susceptible (or tolerant) to low temperature sterilization protocols. While previous reviews have highlighted the need for better understanding of the mechanisms (Mitcham et al., 2006; Phillips and Throne, 2010), none have considered in detail the biochemical interactions between the various stresses of modified gas conditions and low temperature (though see Storey and Storey, 2004). Here we provide an overview of the mechanisms involved in low temperature tolerance and CA responses, both from insect physiology and pest control case studies. The aims of this mini-review are therefore (i) to briefly highlight the biochemical links between the seemingly unrelated stressors of gas and temperature, (ii) identify potential commonalities between stress pathways in order to better understand the mechanisms of low temperature mortality and CA treatments, and (iii) identify future directions for insect physiology research which might be of benefit to applied pest management. 


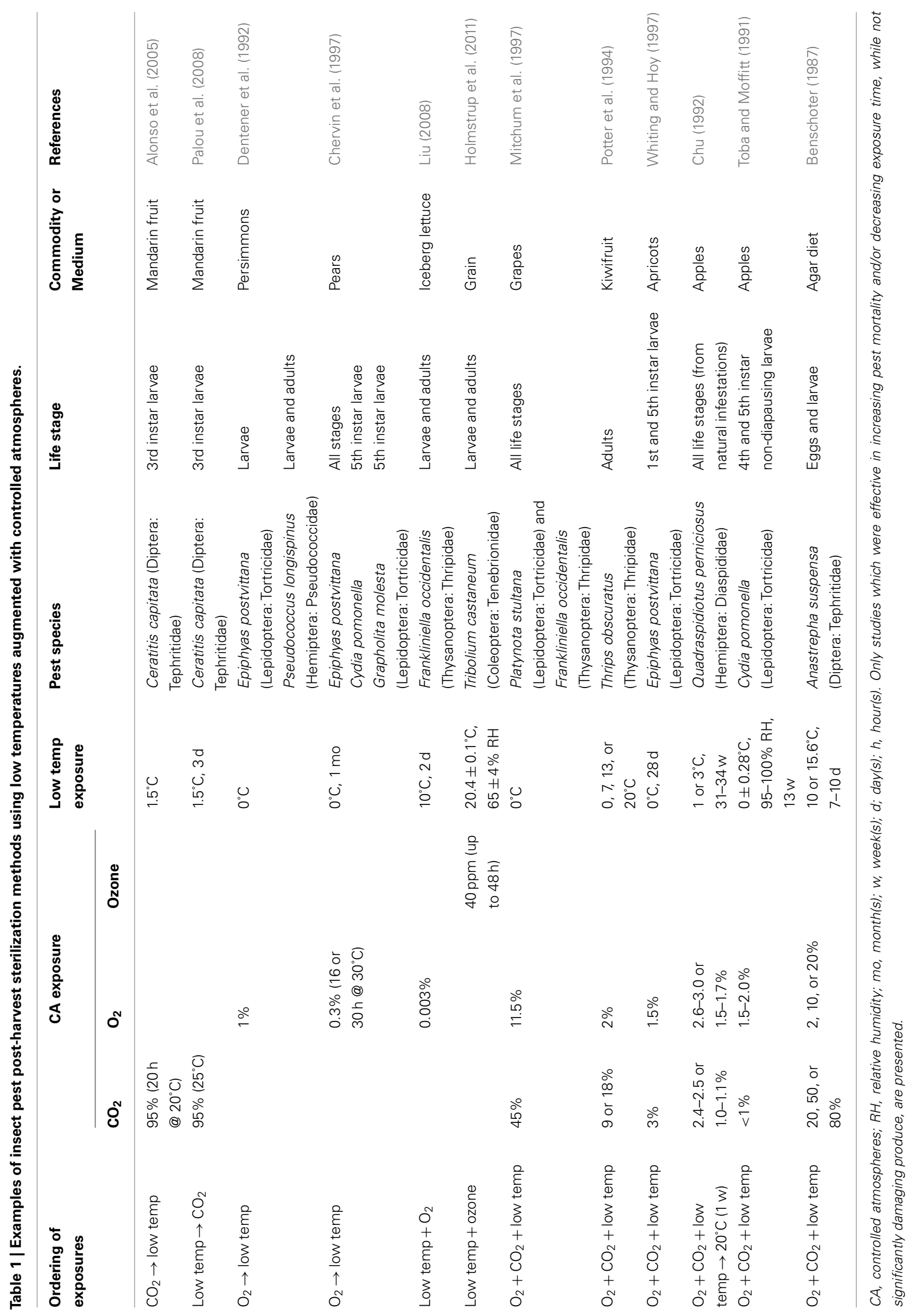




\section{MOLECULAR MECHANISMS OF LOW TEMPERATURE TOLERANCE}

Insect tolerance to low temperature treatments for post-harvest sterilization depends on basal low temperature tolerance, the ability to withstand or repair the stress associated with long-term low temperature exposure, or the ability to rapidly develop biochemical protection (for introduction to this literature, see recent reviews in, e.g., Clark and Worland, 2008; Doucet et al., 2009; Lee, 2010). This ability to rapidly adapt to the external stressor is a form of phenotypic plasticity, in particular, if it occurs within the organism's life-time. Both the immediate environment as well as the species' evolutionary history will determine the extent to which an individuals' response is plastic (e.g., Chown and Terblanche, 2007; Nyamukondiwa et al., 2011; Overgaard et al., 2011).

In most cases, commodities cannot withstand temperatures below freezing and are held at, or just above, $0^{\circ} \mathrm{C}$ for the duration of the treatment. While a large proportion of insects will enter chill coma at these temperatures, and some species or life stages could die (e.g., Drosophila melanogaster survives about $8 \mathrm{~h}$ at $0^{\circ} \mathrm{C}$ ), those with mechanisms of enhanced low temperature tolerance are able to survive more severe exposures. However, such generalizations are complicated by a range of factors. Firstly, it is important to remember that most of these mechanisms are closely linked to one another, as well as to external factors, e.g., diet (see e.g., Shreve et al., 2007). Thus, in order for biochemical mechanisms to buffer the effects of low temperature exposure in an insect, the basic components enabling these processes need to be present, together with active metabolism. These known mechanisms of low temperature tolerance are understood in some detail and rely on interactions between genes, proteins, cryoprotectants, and the regulation of biological membranes to preserve cell structure and function (see Figure $\mathbf{1}$ and Table $\mathbf{2}$ for summary and synthesis).

Ultimately, the gene and biochemical responses described (Table 2) are all dependent on the availability of energy provided by metabolism. The "membrane pacemaker" theory of metabolism provides a link between cellular metabolism and lipid membrane bilayers. It suggests that the balance between monounsaturated and long-chain polyunsaturated acyl chains within the bilayer plays a role in establishing the metabolic rate (reviewed in Hulbert, 2003). Aging membranes will be subjected to a change in acyl

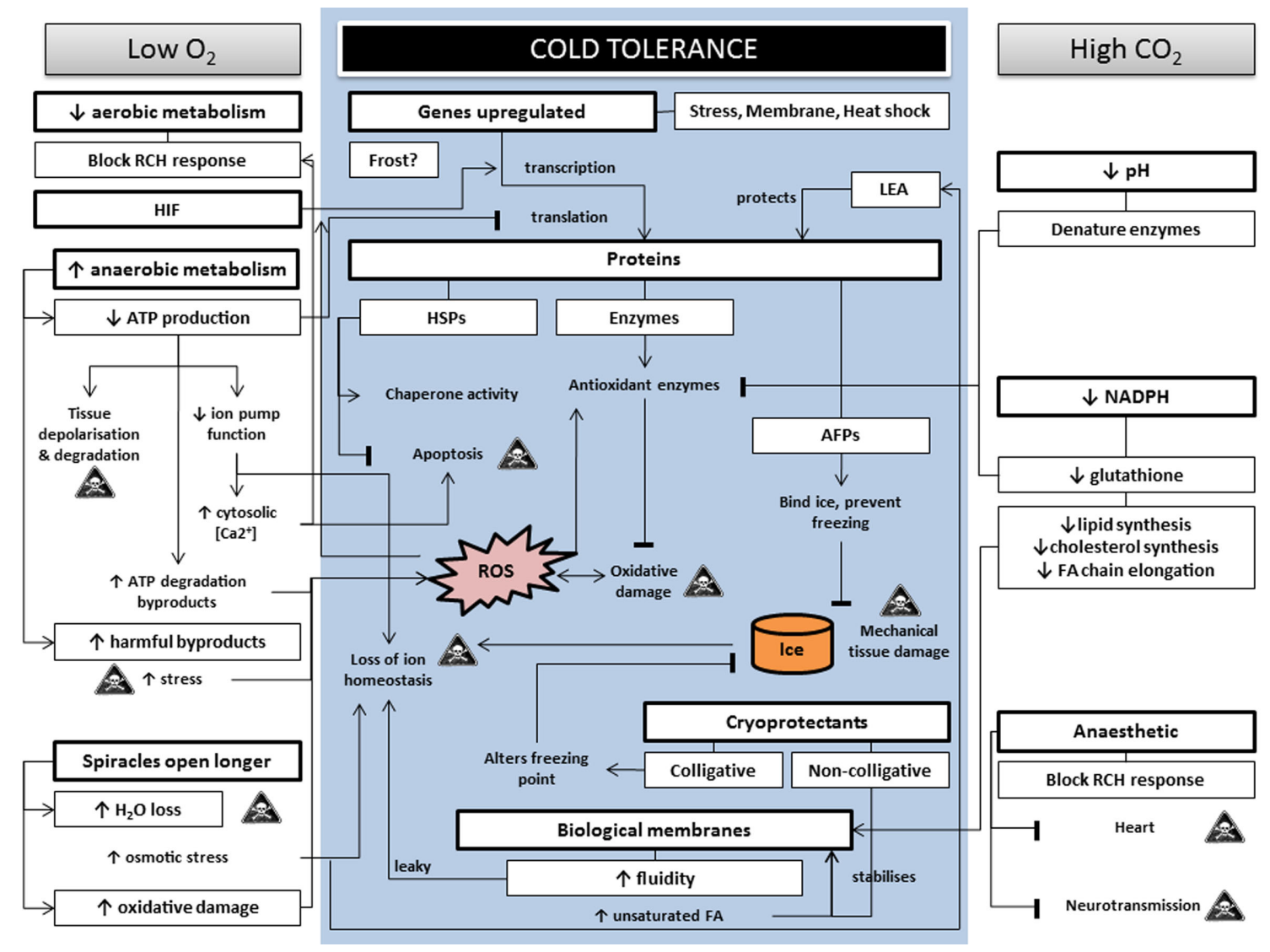

FIGURE 1 | A schematic representation of the cross tolerance between controlled atmospheres (low oxygen and high carbon dioxide) with low temperature stress. The central shaded block represents the mechanisms for survival of low temperatures. Arrows indicate preceding steps in reactions, while solid lines indicate inhibition. The "skull and crossbones" icon represents processes that are likely to lead to mortality. $\mathrm{RCH}$, rapid cold hardening; ATP, adenosine triphosphate; HIF, hypoxia inducible factor; LEA, late embryogenesis abundant proteins; HSPs, heat shock proteins; AFPs, anti-freeze proteins; ROS, reactive oxygen species; FA, fatty acids; NADPH, reduced form of nicotinamide adenine dinucleotide phosphate. 
Table 2 | A summary of mechanisms of insect low temperatures tolerance.

\begin{tabular}{|c|c|c|c|c|}
\hline Molecule(s) & Mode of protection & Cross tolerance (stressors)? & Species & Example reference \\
\hline $\begin{array}{l}\text { Senescence marker } \\
\text { protein-30; } \\
\text { mitochondrial acyl } \\
\text { carrier protein 1; Frost }\end{array}$ & $\begin{array}{l}\text { Unknown (with regard to cold } \\
\text { stress) }\end{array}$ & $\begin{array}{l}\text { Indirect (increased expression } \\
\text { also associated with: heat, } \\
\text { starvation, desiccation)* }^{*}\end{array}$ & Mainly D. melanogaster & $\begin{array}{l}\text { Qin et al. (2005), Morgan } \\
\text { and Mackay (2006), Sinclair } \\
\text { et al. (2007), Colinet et al. } \\
\text { (2010a) }\end{array}$ \\
\hline $\begin{array}{l}\text { Glycerol-3-phosphate } \\
\text { dehydrogenase }\end{array}$ & $\begin{array}{l}\text { Flight behavior; lipid and } \\
\text { carbohydrate metabolism }\end{array}$ & $\begin{array}{l}\text { Indirect (increased expression } \\
\text { or allozyme variation also } \\
\text { associated with: heat, } \\
\text { starvation)* }\end{array}$ & Mainly D. melanogaster & $\begin{array}{l}\text { Barnes et al. (1989), Lee- } \\
\text { mans et al. (2000) }\end{array}$ \\
\hline Desaturase2 & $\begin{array}{l}\text { Fatty acid biosynthesis and } \\
\text { modification }\end{array}$ & $\begin{array}{l}\text { Indirect (increased expression } \\
\text { also associated with: heat, } \\
\text { starvation, desiccation)* }^{*}\end{array}$ & Mainly D. melanogaster & $\begin{array}{l}\text { Morgan and Mackay } \\
\text { (2006), Greenberg et al. } \\
\text { (2006) }\end{array}$ \\
\hline $\begin{array}{l}\text { Heat shock genes and } \\
\text { proteins (HSF, HSP23, } \\
26,70,83, \text { HS-RNA } \omega)\end{array}$ & $\begin{array}{l}\text { Molecular chaperone activity; } \\
\text { Anti-apoptotic activity (blocks } \\
\text { caspase-mediated apoptosis) }\end{array}$ & $\begin{array}{l}\text { Yes (general stress, heat, } \\
\text { desiccation) }\end{array}$ & $\begin{array}{l}\text { Numerous insect } \\
\text { species incl. } D \text {. } \\
\text { melanogaster }\end{array}$ & $\begin{array}{l}\text { Somero (1995), Feder } \\
\text { and Hofmann (1999), } \\
\text { Sørensen et al. (2003), } \\
\text { Sørensen (2010), Colinet } \\
\text { et al. (2010b), Beere et al. } \\
\text { (2000), Jäättelä et al. } \\
\text { (1998) }\end{array}$ \\
\hline $\begin{array}{l}\text { Late embryogenesis } \\
\text { abundant proteins (LEA) }\end{array}$ & $\begin{array}{l}\text { Act as antioxidants or protein and/or } \\
\text { membrane stabilizers }\end{array}$ & Yes (desiccation) & Mainly plants & $\begin{array}{l}\text { Tunnacliffe and Wise } \\
\text { (2007), Hand et al. (2011) }\end{array}$ \\
\hline $\begin{array}{l}\text { Anti-freeze proteins } \\
\text { (AFP) }\end{array}$ & $\begin{array}{l}\text { Increases phase transition } \\
\text { temperature of the membrane }\end{array}$ & & $\begin{array}{l}\text { Polar fish; plants; } \\
\text { insects }\end{array}$ & Tomczak et al. (2002) \\
\hline $\begin{array}{l}\text { Antioxidants (e.g., SOD, } \\
\text { catalase) }\end{array}$ & Reduces oxidative damage & & $\begin{array}{l}\text { Numerous insect } \\
\text { species }\end{array}$ & $\begin{array}{l}\text { Joanisse and Storey (1996), } \\
\text { Hermes-Lima et al. (2001) }\end{array}$ \\
\hline $\begin{array}{l}\text { Membrane composition } \\
\text { (fatty acids, cholesterol) }\end{array}$ & Increases membrane fluidity & & $\begin{array}{l}\text { Sarcophaga bullata; } D . \\
\text { melanogaster; } \\
\text { Caenorhabditis elegans }\end{array}$ & $\begin{array}{l}\text { Lee et al. (2006), Overgaard } \\
\text { et al. (2005), Murray et al. } \\
\text { (2007), M'Baye et al. (2008) }\end{array}$ \\
\hline $\begin{array}{l}\text { Sugars and polyols } \\
\text { (cryoprotectants) }\end{array}$ & $\begin{array}{l}\text { Decreases freezing point; Stabilizes } \\
\text { membranes; chaperone activity; } \\
\text { free radical scavengers }\end{array}$ & Yes (desiccation) & $\begin{array}{l}\text { Numerous insect } \\
\text { species }\end{array}$ & $\begin{array}{l}\text { Koštál et al. (2007), Over- } \\
\text { gaard et al. (2007) }\end{array}$ \\
\hline
\end{tabular}

*Gene information from: Candidate Genes for Climatic Stress Traits in Drosophila. A. A. Hoffmann and co-workers (http://cesar.org.au/index.php?option=com_ candidate_gene.)

composition which may in turn influence a species' lifespan. Interestingly, the carbon units in polyunsaturated acyl chains are very susceptible to oxidative damage, whilst saturated and monounsaturated acyl chains do not possess these carbon atoms (Hulbert, 2003). Molecular changes also occur in the acyl chains' packing which decreases membrane permeability (Tomczak et al., 2002). Additionally, changes in cholesterol content and temperature can result in changes in membrane fluidity by altering the phase of the lipid bilayer (M'Baye et al., 2008).

Thus, an insect's low temperature tolerance depends on interactions between the different molecular levels to ensure function and survival. The cellular mechanisms work together to limit oxidative damage and maintain the integrity of membranes and essential proteins during the low temperature exposure, as well as to buffer the potential heat-stress of returning to warmer temperatures thereafter. A breakdown in just one of these systems is potentially sufficient to stress and overwhelm the entire low temperature tolerance response, perhaps directly or indirectly resulting in insect mortality. In addition, selected tissues may be particularly susceptible to low temperature stress, with knock-on effects for the whole organism if the low temperature-sensitive tissue becomes irreparably damaged (e.g., MacMillan and Sinclair, 2011).

\section{AUGMENTATION WITH MANIPULATED ATMOSPHERES}

Pörtner (2001) proposed a theory for thermal tolerance of animals that centered round $\mathrm{O}_{2}$ limitation as the major factor. The theory of $\mathrm{O}_{2}$ and capacity limitation of thermal tolerance (OCLT) proposes that once aerobic capacity has been exhausted at temperatures close to critical limits, anaerobic mitochondrial metabolism begins. Although this theory was proposed for marine animals, it is plausible that $\mathrm{O}_{2}$ limitation may induce a similar sequence of mechanisms responsible for insect low temperature tolerance. To date, little evidence supporting the OCLT has been found in insects (e.g., Klok et al., 2004; Stevens et al., 2010; but see Verberk and Bilton, 2011). Regardless, OCLT serves as an important theory which requires further testing since it has direct applicability to understanding the mechanisms of thermal death (Stevens et al., 2010; Verberk and Bilton, 2011). 
In the next section, we briefly consider the cellular responses induced by low $\mathrm{O}_{2}$ in insects, followed by responses to high $\mathrm{CO}_{2}$ and ozone.

\section{OXYGEN}

Responses to low $\mathrm{O}_{2}$ can be broadly classified into two classes: the regulating class and the conforming class (Hochachka, 1991; Makarieva et al., 2006). Organisms in the regulating class maintain the energy required for normal processing during the exposure by increasing glycolytic flux and using large amounts of substrates, while those in the conforming class decrease energy use, respiration rate, and substrate usage without engaging in glycolytic pathways. Organisms in the conforming class will usually survive long-term exposures to low $\mathrm{O}_{2}$ better than those in the regulating class. Damage repair processes are ongoing in the regulating class and only occur upon return to normoxia in the conforming class; repair mechanisms are nevertheless essential for survival of hypoxia.

Insects exposed to hypoxia (or anoxia) will decrease aerobic metabolism, which has been shown to block rapid cold hardening $(\mathrm{RCH})$ in the housefly, Musca domestica (Coulson and Bale, 1991). Similarly, Nilson et al (2006) showed that anoxia blocked $\mathrm{RCH}$ in D. melanogaster after $1 \mathrm{~h}$ of exposure, but had no effect at shorter times. RCH is a form of phenotypic plasticity whereby a non-lethal low temperature "shock" protects against subsequent, previously lethal, low temperature exposure (Lee et al., 1987; Lee and Denlinger, 2010). In contrast, Yocum and Delinger (1994) found that $\mathrm{RCH}$ is not induced under anoxic conditions in the flesh fly (Sarcophaga crassipalpis) indicating that these processes required aerobic conditions to occur. It is therefore clear that gas conditions may interact with low temperature stress responses in at least some species.

The decrease in aerobic metabolism caused by decreasing temperature can be accompanied by a switch to anaerobic metabolism, which can be detrimental if experienced for long periods (Figure 1). Increased anaerobic metabolism decreases the amount of adenosine triphosphate (ATP) production which, in turn, can depolarize and degrade tissues, increase ATP degradation and reduce the functioning of ion pumps (e.g., Chiappini et al., 2009). Byproducts of ATP degradation can react with $\mathrm{O}_{2}$ to form reactive oxygen species (ROS) that cause oxidative damage (Weyel and Wegener, 1996), while a malfunctioning of ion pumps will increase cytosolic calcium concentrations which, if left unbuffered, can trigger apoptosis and block RCH (reviewed by Orrenius et al., 2003; Teets et al., 2008). However, during hypoxia, coprophilous beetles are able to extract sufficient $\mathrm{O}_{2}$ from air that contained a very low concentration of $\mathrm{O}_{2}(1 \%)$ without switching to anaerobic metabolism, which suggests that not all insects are affected in the same way (Holter and Spangenberg, 1997). In addition, during hypoxia insects may keep their spiracles open for longer periods in order to meet their $\mathrm{O}_{2}$ demands (Hetz and Bradley, 2005). Opening of the spiracles can lead to an increased water loss rate, which is believed to be how low $\mathrm{O}_{2}$ concentrations can augment a low temperature sterilization regime (Navarro, 1978). Based on studies of insect gas exchange, keeping spiracles open for long periods may result in oxidative damage (Hetz and Bradley, 2005) - possibly through the formation of ROS acting as a signaling mechanism
(Boardman et al., 2011). In addition, hypoxia also stimulates hypoxia inducible factor (HIF), a transcription factor stabilized by the presence of ROS, which is necessary for the upregulation of hypoxia-responsive genes (Huang et al., 1996).

\section{CARBON DIOXIDE}

High $\mathrm{CO}_{2}$ concentrations may decrease $\mathrm{pH}$ which can be detrimental to membranes and cellular function. A decrease in $\mathrm{pH}$ will also denature enzymes, including antioxidant enzymes needed for low temperature tolerance, especially if there are no additional heat shock proteins (HSPs) to act as chaperones. In addition, high $\mathrm{CO}_{2}$ causes a decrease in NADPH (reduced form of nicotinamide adenine dinucleotide phosphate) enzyme and a subsequent decrease in glutathione production (Friedlander, 1983). NADPH and the antioxidant glutathione are involved in protecting against the toxicity of ROS, while NADPH also contributes to lipid synthesis, cholesterol synthesis, and fatty acid chain elongation.

Secondly, high concentrations of $\mathrm{CO}_{2}$ are commonly used as an anesthetic for insect handling. Identical to low $\mathrm{O}_{2}, \mathrm{CO}_{2}$ anesthesia blocked RCH in D. melanogaster after $1 \mathrm{~h}$ of exposure, but had no effect at shorter times (Nilson et al., 2006). Badre et al. (2005) investigated the mechanism underlying this response and found that in D. melanogaster larvae, with intact spiracles, high $\mathrm{CO}_{2}$ caused their hearts to stop, and blocked synaptic transmission at the neuromuscular junction by decreasing the number of glutamate receptors. Further investigations showed that these effects were not due to hypoxia, low $\mathrm{pH}$, or action of the central nervous system.

\section{OZONE}

Recently, there has been increased research into the use of ozone, a strong oxidizing agent, for pest control in stored products (e.g., Tiwari et al., 2010; Holmstrup et al., 2011). The mechanisms of action of ozone are attributed to an increase in ROS, together with direct deleterious reactions with proteins, DNA, and polyunsaturated fatty acids (Hermes-Lima, 2004).

\section{IMPLICATIONS OF INTERACTIONS BETWEEN TEMPERATURE AND ATMOSPHERE}

Figure 1 illustrates some of the potential biochemical mechanisms of cross tolerance of CAs with low temperature tolerance, and shows how the altered gas conditions can potentially interfere with typical low temperature tolerance mechanisms. Simply put, low $\mathrm{O}_{2}$ decreases aerobic metabolism which, apart from directly blocking $\mathrm{RCH}$ responses, decreases transcription and ion homeostasis, and increases oxidative damage. Furthermore, water loss rate is increased through the opening of the spiracles, perhaps leading to increased osmotic and ionic stress, and downstream oxidative damage. High $\mathrm{CO}_{2}$ directly affects the heart and nervous system (anesthetic effects), and decreases $\mathrm{pH}$ and NADPH which affect the antioxidant response and membrane functioning. Any one (or combination) of these factors may be the key reason as to why survival may be reduced under combination CA low temperature treatments. Yet some observations suggest that survival may improve under these combination treatments. Possible reasons for the improved survival may be cross tolerance between temperature and gases (where the mechanisms of either low temperature or gas tolerance are sufficiently protective against 
both stresses to ensure survival) or natural tolerance to one or more of the potential stressors.

At high temperatures, heat hardening can also benefit insects by increasing survival at previously lethal high temperatures, as well as upregulating general stress responses. While high temperature responses fall largely outside the scope of this review, the physiological and biochemical changes that insects undergo to survive high temperature shock may provide insights into how they survive low temperature shock. Moreover, cross tolerance to temperature stress has been demonstrated in a variety of species (e.g., Burton et al., 1988; Chen et al., 1991; Sinclair and Chown, 2003). The heat shock transcription factor that regulates HSPs induces stress-associated genes, including some HSPs, after longterm low temperature acclimation, but typically these do not play a role in resistance to low temperature shock, $\mathrm{RCH}$, or high temperature knock-down in D. melanogaster (Nielsen et al., 2005). Therefore, any stress of heat exposure prior to CA low temperature sterilization may inadvertently improve survival of the insect pest through cross tolerance of low and high temperatures, as well as low temperatures and desiccation stress.

\section{INNATE TOLERANCE TO EXTREME ATMOSPHERES}

Controlled atmospheres can also occur naturally in an insects' immediate environment. For example, insects living at high altitudes will experience hypoxic conditions (Frazier et al., 2006), while those that burrow underground or live in dung pats may experience both hypoxic and hypercapnic (high $\mathrm{CO}_{2}$ ) conditions (Holter and Spangenberg, 1997). Thus, some pest species may be pre-adapted for survival to CAs, and it may be argued that an understanding of basic ecology and biology may be important for selecting effective treatments and understanding why certain treatments fail to increase mortality. In addition, the adaptations present in these organisms may highlight the mechanisms that are needed to ensure survival under these conditions and, in turn, reveal insights into the cellular or whole organism physiological systems responsible for mortality under altered environmental conditions.

Some insects are naturally more tolerant of changes in gas concentrations during specific life stages. For example, embryos of D. melanogaster are able to arrest the cell cycle at the metaphase or S-phase in response to hypoxia, and will resume normal cell cycling within 20 min of reoxygenation (Douglas et al., 2001). In addition to the cell cycle arrest, $D$. melanogaster are able to detect the $\mathrm{O}_{2}$ changes through the accumulation of nitric oxide in sensor cells in order to change their behavior, and alter tracheal development, possibly with the aid of HIF (Wingrove and O'Farrell, 1999). Similarly, pupae of Tribolium confusum are able to survive $48 \mathrm{~h}$ of anoxia, but die if the anoxia continues beyond this point, possibly due to depletion in carbohydrate stores by anaerobic glycolysis (Kennington and Cannell, 1967).

\section{REFERENCES}

Alonso, M., del Rio, M. A., and Jacas, J. A. (2005). Carbon dioxide diminishes cold tolerance of third instar larvae of Ceratitis capitata Wiedemann (Diptera: Tephritidae) in "Fortune" mandarins: implications for citrus

Tolerance to gases is aided by the insects' ability to withstand reoxygenation. After anoxia, return to normoxia has been shown to cause damage in both $D$. melanogaster (Lighton and Schilman, 2007) and other vertebrate species (Hermes-Lima and ZentenoSavín, 2002). One possible cause of increased hypoxia/anoxia tolerance may be the ability to return to efficient energy metabolism, without generating excess heat, upon reoxygenation (Wegener and Moratzky, 1995). During anoxia, ATP is degraded and the resulting byproducts can react with $\mathrm{O}_{2}$ to become ROS (Figure 1). The ability of insects to recover from anoxia may be further attributed to their ability to limit the degradation of adenine nucleotides during anoxia, and re-synthesize ATP from these nucleotides during recovery (Weyel and Wegener, 1996).

\section{CONCLUSION AND FUTURE DIRECTIONS}

Reactions to similar treatments vary widely between insect species, hence treatment regimes should be investigated in a speciesspecific manner, based on the known physiology and biochemical responses of each species (Navarro, 1978). Species relatedness may aid generalizing thermal tolerance and its plasticity but even then should be undertaken with caution (e.g., Nyamukondiwa et al., 2011). Established thermal responses or lack thereof should be used as background information to determine which treatments may be worth testing to determine their suitability for post-harvest sterilization or control of grain pests. Furthermore, as emphasized in this mini-review, there is a large degree of overlap between the mechanisms of gas and temperature stress responses. Tolerance to these stressors depends largely on limiting oxidative damage and maintaining the integrity of biological membranes and essential proteins. The success of CA augmentation of low temperature treatments may be attributed to their ability to interfere with basal low temperature tolerance mechanisms, causing sufficient cellular and/or tissue damage to result in insect mortality, or perhaps influencing damage and repair mechanisms during recovery periods from CAs. Future work aimed at expanding the potentiating and blocking types of action in these stress pathways, and the interactions among them, will likely enhance both applied pest management, as well as understanding of whole organism physiology to extreme conditions.

\section{ACKNOWLEDGMENTS}

The authors wish to thank Citrus Research International, Fruitgro Science, NRF-THRIP and Sub-committee B (Stellenbosch University) for financial support and the two referees for constructive comments on an early version of the manuscript. This work was partly supported by the National Research Foundation IFR 2011032600009 to John S. Terblanche. Any opinion, findings, and conclusions or recommendations expressed in this material are those of the authors and therefore the NRF do not accept liability thereto.

Physiol. A Mol. Integr. Physiol. 140, 363-376.

Biol. Technol. 36, 103-111.

Badre, N. H., Martin, M. E., and Cooper, R. L. (2005). The physiological and behavioral effects of carbon dioxide on Drosophila melanogaster larvae. Comp. Biochem.
Barnes, P. T., Holland, B., and Courreges, V. (1989). Genotype-byenvironment and epistatic interactions in Drosophila melanogaster: the effects of Gpdh allozymes, genetic background and rearing temperature on larval developmental time and viability. Genetics 122, 859-868.

Beere, H. M., Wolf, B. B., Cain, K., Mosser, D. D., Mahboubi, A., Kuwana, T., Tailor, P., Morimoto, R. I., Cohen, G. M., and Green, 
D. R. (2000). Heat-shock protein 70 inhibits apoptosis by preventing recruitment of procaspase- 9 to the Apaf-1 apoptosome. Nat. Cell Biol. 2, 469-475.

Benschoter, C. A. (1987). Effects of modified atmosphere and refrigeration temperatures on survival of eggs and larvae of the Caribbean fruit fly (Diptera: Tephritidae) in laboratory diet. J. Econ. Entomol. 80, 1223-1225.

Boardman, L., Terblanche, J. S., Hetz, S. K., Marais, E., and Chown, S. L. (2011). Reactive oxygen species and discontinuous gas exchange in insects. Proc. Biol. Sci. doi:10.1098/rspb.2011.1243

Burton, V., Mitchell, H. K., Young, P., and Petersen, N. S. (1988). Heat shock protection against cold stress of Drosophila melanogaster. Mol. Cell. Biol. 8, 3550-3552.

Chen, C. P., Lee, R. E., and Denlinger, D. L. (1991). Cold shock and heatshock - a comparison of the protection generated by brief pretreatment at less severe temperatures. Physiol. Entomol. 16, 19-26.

Chervin, C., Kulkarni, S., Kreidl, S., Birrell, F., and Glenn, D. (1997). A high temperature/low oxygen pulse improves cold storage disinfestations. Postharvest Biol. Technol. 10, 239-245.

Chiappini, E., Molinari, P., and Cravedi, P. (2009). Mortality of Tribolium confusum J. du Val (Coleoptera: Tenebrionidae) in controlled atmospheres at different oxygen percentages. J. Stored Prod. Res. 45, 10-13.

Chown, S. L., and Terblanche, J. S. (2007). Physiological diversity in insects: ecological and evolutionary contexts. Adv. In Insect Phys. 33, 50-152.

Chu, C. L. (1992). Postharvest control of San Jose scale on apples by controlled atmosphere storage. Postharvest Biol. Technol. 1, 361-369.

Clark, M. S., and Worland, M. R. (2008). How insects survive the cold: molecular mechanisms-a review. J. Comp. Physiol. B Biochem. Syst. Environ. Physiol. 178, 917-933.

Colinet, H., Fai Lee, S., and Hoffmann, A. (2010a). Functional characterization of the Frost gene in Drosophila melanogaster: importance for recovery from chill coma. PLoS ONE 5, e10925. doi:10.1371/journal.pone.0010925

Colinet, H., Fai Lee, S., and Hoffmann, A. (2010b). Temporal expression of heat shock genes during cold stress and recovery from chill coma in adult Drosophila melanogaster. FEBS J. 277, 174-185.
Coulson, S. J., and Bale, J. S. (1991). Anoxia induces rapid cold hardening in the housefly Musca domestica (Diptera, Muscidae). J. Insect Physiol. 37, 497-501.

Dentener, P. R., Peetz, S. M., and Birtles, D. B. (1992). Modified atmospheres for the postharvest disinfestation of New Zealand persimmons. N. Z. J. Crop Hortic. Sci. 20, 203-208.

Doucet, D., Walker, V. K., and Qin, W. (2009). The bugs that came in from the cold: molecular adaptations to low temperatures in insects. Cell. Mol. Life Sci. 66, 1404-1418.

Douglas, R. M., Xu, T., and Haddad, G. G. (2001). Cell cycle progression and cell division are sensitive to hypoxia in Drosophila melanogaster embryos. Am. J. Physiol. Regul. Integr. Comp. Physiol. 280, R1555R1563.

Feder, M. E., and Hofmann, G. E. (1999). Heat-shock proteins, molecular chaperones, and the stress response: evolutionary and ecological physiology. Annu. Rev. Physiol. 61, 243-282.

Fields, P. G., and White, N. D. G. (2002). Alternatives to methyl bromide treatments for stored-product and quarantine insects. Annu. Rev. Entomol. 47, 331-359.

Frazier, M. R., Dillon, M. E., and Crane, S. (2006). Altitudinal clines in insect body size: physiological interpretations of mixed patterns. Integr. Comp. Biol. 46, E193.

Friedlander, A. (1983). "Biochemical reflection on a non-chemical control method: the effect of controlled atmosphere on the biochemical processes in stored product insects," in Proceedings, 3rd International Working Conference on Stored Product Entomology (Manhattan: Kansas State University), 471-486.

Greenberg, A. J., Moran, J. R., Fang, S., and Wu, C. -I. (2006). Adaptive loss of an old duplicated gene during incipient speciation. Mol. Biol. Evol. $23,401-410$.

Hallman, G. J., and Denlinger, D. L. (eds). (1998). Temperature Sensitivity in Insects and Application in Integrated Pest Management. Boulder, CO: Westview Press.

Hand, S. C., Menze, M. A., Toner, M., Boswell, L., and Moore, D. (2011). LEA proteins during water stress: not just for plants anymore. Annu. Rev. Physiol. 73, 115-134.

Hermes-Lima, M. (2004). "Oxygen in biology and biochemistry: role of free radicals," in Functional Metabolism: Regulation and Adaptation, ed. K. B. Storey (Hoboken: John Wiley and Sons, Inc.), 319-368.
Hermes-Lima, M., Storey, J. M., and Storey, K. B. (2001). "Antioxidant defenses and animal adaptation to oxygen availability during environmental stress," in Cell and Molecular Response to Stress Protein Adaptations and Signal Transduction, ed. K. B. Storey (Amsterdam: Elsevier), 263-287.

Hermes-Lima, M., and Zenteno-Savín, T. (2002). Animal responses to drastic changes in oxygen availability and physiological oxidative stress. Comp. Biochem. Physiol. C Comp. Pharmacol. Toxicol. 133, 537-556.

Hetz, S. K., and Bradley, T. J. (2005). Insects breathe discontinuously to avoid oxygen toxicity. Nature 433, 516-519.

Hochachka, P. W. (1991). "Metabolic strategies of defense against hypoxia in animals," in Plant Life Under Oxygen Deprivation, eds M. B. Jackson, D. D. Davies, and H. Lambers (Hague: SPB Academic Publishing), 121-128.

Holmstrup, M., Sørensen, J. G., Heckmann, L.-H., Slotsbo, S., Hansen, P. and Hansen, L. S. (2011). Effects of ozone on gene expression and lipid peroxidation in adults and larvae of the red flour beetle (Tribolium castaneum). J. Stored Prod. Res. 47, 378-384.

Holter, P., and Spangenberg, A. (1997). Oxygen uptake in coprophilous beetles (Aphodius, Geotrupes, Sphaeridium) at low oxygen and high carbon dioxide concentrations. Physiol. Entomol. 22, 339-343.

Huang, L. E., Arany, Z., Livingston, D. M., and Bunn, H. F. (1996). Activation of hypoxia inducible transcription factor depends primarily on redox-sensitive stabilization of 580 its $\alpha$ subunit. J. Biol. Chem. 271, 32253-32259.

Hulbert, A. J. (2003). Life, death and membrane bilayers. J. Exp. Biol. 206, 2303-2311.

Jäättelä, M., Wissing, D., Kokholm, K., Kallunki, T., and Egeblad, M. (1998). Hsp70 exerts its anti-apoptotic function downstream of caspase3-like proteases. EMBO J. 17, 6124-6134.

Joanisse, D. R., and Storey, K. B. (1996) Oxidative stress and antioxidants in overwintering larvae of cold-hardy goldenrod gall insects. J. Exp. Biol. 199, 1483-1491.

Kennington, G. S., and Cannell, S. (1967). Biochemical correlates of respiratory and developmental changes in anoxic Tribolium confusum pupae. Physiol. Zool. 40, 403-408.
Klok, C. J., Sinclair, B. J., and Chown, S. L. (2004). Upper thermal tolerance and oxygen limitation in terrestrial arthropods. J. Exp. Biol. 207, 2361-2370.

Koštál, V., Zahradnikova, H., Simek, P., and Zeleny, J. (2007). Multiple component system of sugars and polyols in the overwintering spruce bark beetle, Ips typographus. J. Insect Physiol. 53, 580-586.

Lee, R. E. (2010). "A primer on insect cold-tolerance," in Low temperature Biology of Insects, eds D. L. Denlinger and R. E. Lee (Cambridge: Cambridge University Press), 3-34.

Lee, R. E., Chen, C. P., and Denlinger, D. L. (1987). A rapid coldhardening process in insects. Science 238, 1415-1417.

Lee, R. E., Damodaran, K., Yi, S. X. and Lorigan, G. A. (2006). Rapid cold-hardening increases membrane fluidity and cold tolerance of insect cells. Cryobiology 52, 459-463.

Lee, R. E., and Denlinger, D. L. (2010). "Rapid cold-hardening: ecological significance and underpinning mechanisms," in Low temperature Biology of Insects, eds D. L. Denlinger and R. E. Lee (Cambridge: Cambridge University Press), 35-57.

Leemans, R., Egger, B., Loop, T., Kammermeier, L., He, H., Hartmann, B., Certa, U., Hirth, F., and Reichert, H. (2000). Quantitive transcript imaging in normal and heatshocked Drosophila embryos by using high-density oligonucleotide arrays. Proc. Natl. Acad. Sci. U.S.A. 97, 12138-12143.

Lighton, J. R. B., and Schilman, P. E. (2007). Oxygen reperfusion damage in an insect. PLoS ONE 12, e1267. doi:10.1371/journal.pone.0001267

Liu, Y. B. (2008). Ultralow oxygen treatment for postharvest control of western flower thrips, Frankliniella occidentalis (Thysanoptera: Thripidae), on iceberg lettuce I. Effects of temperature, time, and oxygen level on insect mortality and lettuce quality. Postharvest Biol. Technol. 49, 129-134.

MacMillan, H., and Sinclair, B. J. (2011). The role of the gut in insect chillinginjury: cold-induced disruption of osmoregulation in the fall field cricket, Gryllus pennsylvanicus. J. Exp. Biol. 214, 726-734.

Makarieva, A. M., Gorshkov, V. G., Li, B.-L., and Chown, S. L. (2006). Sizeand temperature-independence of minimum life-supporting metabolic rates. Funct. Ecol. 20, 83-96. 
M’Baye, G., Mely, Y., Duportail, G., and Klymchenko, A. S. (2008). Liquid ordered and gel phases of lipid bilayers: fluorescent probes reveal close fluidity but different hydration. Biophys. J. 95, 1217-1225.

Mitcham, E., Martin, T., and Zhou, S. (2006). The mode of action of insecticidal controlled atmospheres. Bull. Entomol. Res. 96, 213-222.

Mitcham, E. J., Zhou, S., and Kader, A. A. (2001). Potential of CA for Postharvest Insect Control in Fresh Horticultural Perishables: An Update of Summary Tables Compiled by Ke and Kader 1992. Davis, CA: Department of Pomology, University of California.

Mitchum, E. J., Zhou, S., and Bikoba, V. (1997). Controlled atmospheres for quarantine control of three pests of table grapes. J. Econ. Entomol. 90, 1360-1370.

Morgan, T. J., and Mackay, T. F. C. (2006). Quantitative trait loci for thermotolerance phenotypes in Drosophila melanogaster. Heredity 96, 232-242.

Murray, P., Hayward, S. A. L., Govan, G. G., Gracey, A. Y., and Cossins, A. R. (2007). An explicit test of the phospholipid saturation hypothesis of acquired cold tolerance in Caenorhabditis elegans. Proc. Natl. Acad. Sci. U.S.A. 104, 5489-5494.

Navarro, S. (1978). The effects of low oxygen tensions on three storedproduct insect pests. Phytoparasitica 6, 51-58.

Neven, L. G., and Rehfield-Ray, L. (2006). Confirmation and efficacy tests against codling moth and oriental fruit moth in apples using combined heat and controlled atmosphere treatments. J. Econ. Entomol. 99, 1620-1627.

Nielsen, M. M., Overgaard, J., Sorensen, J. G., Holmstrup, M., Justesen, J., and Loeschcke, V. (2005). Role of HSF activation for resistance to heat, cold and high-temperature knock-down. J. Insect Physiol. 51, 1320-1329.

Nilson, T. L., Sinclair, B. J., and Roberts, S. P. (2006). The effects of carbon dioxide anesthesia and anoxia on rapid cold-hardening and chill coma recovery in Drosophila melanogaster. J. Insect Physiol. 52, 1027-1033.

Nyamukondiwa, C., Terblanche, J. S., Marshall, K. E., and Sinclair, B. J. (2011). Basal cold but not heat tolerance constrains plasticity among Drosophila species (Diptera: Drosophilidae). J. Evol. Biol. 24, 1927-1938.

Orrenius, S., Zhivotovsky, B., and Nicotera, P. (2003). Regulation of cell death: the calcium-apoptosis link. Nat. Rev. Mol. Cell Biol. 4, 552-565.

Overgaard, J., Kristensen, T. N., Mitchell, K. A., and Hoffmann, A. A. (2011). Thermal tolerance in widespread and tropical Drosophila species: does phenotypic plasticity increase with latitude? Am. Nat. 178(Suppl. 1), S80-S96.

Overgaard, J., Malmendal, A., Sørensen, J. G., Bundy, J. G., Loeschcke, V., Nielsen, N. C., and Holmstrup, M. (2007). Metabolomic profiling of rapid cold hardening and cold shock in Drosophila melanogaster. J. Insect Physiol. 53, 1218-1232.

Overgaard, J., Sørensen, J. G., Petersen, S. O., Loeschcke, V., and Holmstrup, M. (2005). Changes in membrane lipid composition following rapid cold hardening in Drosophila melanogaster. J. Insect Physiol. 51, 1173-1182.

Palou, L., Jacas, J. A., Marcilla, A., Alonso, M., and del Rio, M. A. (2008). Physico-chemical and sensory quality of "Clemenules" mandarins and survival of the Mediterranean fruit fly as affected by complementary cold and carbon dioxide. Postharvest Biol. Technol. 48, 443-450.

Phillips, T. W., and Throne, J. E. (2010). Biorational approaches to managing stored-product insects. Annu. Rev. Entomol. 55, 375-397.

Pörtner, H. O. (2001). Climate change and temperature-dependent biogeography: oxygen limitation of thermal tolerance in animals. Naturwissenschaften $88,137-146$.

Potter, M. A., Carpenter, A., Stocker, A., and Wright, S. (1994). Controlled atmospheres for postharvest disinfestation of Thrips obscuratus (Thysanoptera: Thripidae). J. Econ. Entomol. 87, 1251-1255.

Pryke, J. S., and Pringle, K. L. (2008). Postharvest disinfestations treatments for deciduous and citrus fruits of the Western Cape, South Africa: a database analysis. S. Afr. J. Sci. 104, 85-89.

Qin, W., Neal, S. J., Robertson, R. M., Westwood, J. T., and Walker, V. K. (2005). Cold hardening and transcriptional change in Drosophila melanogaster. Insect Mol. Biol. 14, 607-613.

Shreve, S. M., Yi, S. X., and Lee, R. E. (2007). Increased dietary cholesterol enhances cold tolerance in Drosophila melanogaster. Cryo Letters 28, 33-37.

Sinclair, B. J., and Chown, S. L. (2003). Rapid responses to high temperature and desiccation but not to low temperature in the freeze tolerant sub-Antarctic caterpillar Pringleophaga marioni (Lepidoptera, Tineidae). J. Insect Physiol. 49, 45-52.

Sinclair, B. J., Gibbs, A. G., and Roberts, S. P. (2007). Gene transcription during exposure to, and recovery from, cold and desiccation stress in Drosophila melanogaster. Insect Mol. Biol. 16, 435-443.

Somero, G. N. (1995). Proteins and temperature. Annu. Rev. Physiol. 57, 43-68.

Sørensen, J. G. (2010). Application of heat shock protein expression for detecting natural adaptation and exposure to stress in natural populations. Curr. Zool. 56, 703-713.

Sørensen, J. G., Kristensen, T. N., and Loeschcke, V. (2003). The evolutionary and ecological role of heat shock proteins. Ecol. Lett. 6, 1025-1037.

Stevens, M. M., Jackson, S., Bester, S. A., Terblanche, J. S., and Chown, S. L. (2010). Oxygen limitation and thermal tolerance in two terrestrial arthropod species. J. Exp. Biol. 213, 2209-2218.

Storey, K. B., and Storey, J. M. (2004). "Cold hardiness and freeze tolerance," in Functional Metabolism: Regulation and Adaptation, ed. K. B. Storey (New Jersey: Wiley-Liss, Inc.), 473-503.

Teets, N. M., Elnitsky, M. A., Benoit, J. B., Lopez-Martinez, G., Denlinger, D. L., and Lee, R. E. (2008). Rapid coldhardening in larvae of the Antarctic midge Belgica antarctica: cellular cold-sensing and a role for calcium. Am. J. Physiol. Regul. Integr. Comp. Physiol. 294, R1938-R1946.

Tiwari, B. K., Brennan, C. S., Curran, T., Gallagher, E., Cullen, P. J., and Donnell, C. P. (2010). Application of ozone in grain processing. J. Cereal Sci. 51, 248e255.

Toba, H. H., and Moffitt, H. R. (1991). Controlled atmosphere cold storage as a quarantine treatment for nondiapausing codling moth (Lepidoptera: Tortricidae) larvae in apples. J. Econ. Entomol. 84, 1316-1319.

Tomczak, M. M., Hincha, D. K., Estrada, S. D., Wolkers, W. F., Crowe, L. M., Feeney, R. E., Tablin, F., and Crowe, J. H. (2002). A mechanism for stabilization of membranes at low temperatures by an antifreeze protein. Biophys. J. 82, 874-881.

Tunnacliffe, A., and Wise, M. J. (2007). The continuing conundrum of the LEA proteins. Natuurwissenschaften 94, 791-812.
Verberk, W. C. E. P., and Bilton, D. T. (2011). Can oxygen set thermal limits in an insect and drive gigantism? PLoS One 6, e22610. doi:10.1371/journal.pone.0022610

Wegener, G., and Moratzky, T. (1995). Hypoxia and anoxia in insects: microcalorimetric studies on two species (Locusta migratoria and Manduca sexta) showing different degrees of anoxia tolerance. Thermochim. Acta 251, 209-218.

Weyel, W., and Wegener, G. (1996). Adenine nucleotide metabolism during anoxia and postanoxic recovery in insects. Experientia 52, 474-480.

Whiting, D. C., and Hoy, L. E. (1997). "Mortality response of light brown apple moth to a controlled atmosphere cold storage treatment for apricots," in Proceedings of 50th New Zealand Plant Protection Conference, Lincoln, 431-435.

Wingrove, J. A., and O'Farrell, P. H. (1999). Nitric oxide contributes to behavioural, cellular, and developmental responses to low oxygen in Drosophila. Cell 98, 105-114.

Yocum, G. D., and Delinger, D. L. (1994). Anoxia blocks thermotolerance and the induction of rapid cold hardening in the fresh fly, Sarcophaga crassipalpis. Physiol. Entomol. 19, 152-158.

Conflict of Interest Statement: The authors declare that the research was conducted in the absence of any commercial or financial relationships that could be construed as a potential conflict of interest.

Received: 09 September 2011; paper pending published: 03 October 2011; accepted: 15 November 2011; published online: 02 December 2011.

Citation: Boardman L, Sørensen JG, Johnson SA and Terblanche JS (2011) Interactions between controlled atmospheres and low temperature tolerance: a review of biochemical mechanisms. Front. Physio. 2:92. doi: 10.3389/fphys.2011.00092

This article was submitted to Frontiers in Invertebrate Physiology, a specialty of Frontiers in Physiology.

Copyright (c) 2011 Boardman, Sørensen, Johnson and Terblanche. This is an openaccess article subject to a non-exclusive license between the authors and Frontiers Media SA, which permits use, distribution and reproduction in other forums, provided the original authors and source are credited and other Frontiers conditions are complied with. 